\section{Military Technical College Kobry El-Kobbah, Cairo, Egypt}

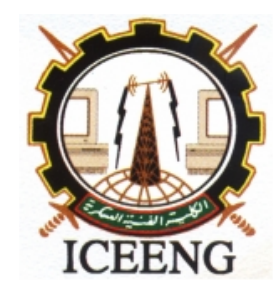

\section{$8^{\text {th }}$ International Conference on Electrical Engineering \\ ICEENG 2012}

\title{
Wind Energy: Past, Present and Future
}

$$
\text { By }
$$
A. A. AbdElhafez*
J. I. AL-Sadey**
R. M. Al-Bouthigy**

\section{$\underline{\text { Abstract: }}$}

The wind energy is a strong candidate for supplying the escalating world energy requirements. The wind energy enjoys: environmental compatibility, economical feasibility and sustainability. Although the commercial production of electricity from wind is commenced worldwide; however, the capability of Arabic nations to cope with the global move into replacing fossil fuels with the renewable energy sources is still under investigation. Therefore, this paper addresses the technical/ economical challenges of utilizing wind energy in Arabic world. Two study cases for Egypt and Yemen are considered for thoroughly investigation. These countries represent the major of the Arabic world in terms of shortage of fossil fuels and the increased demand on energy. The paper also presents a brief introduction into wind-based electricity. The main elements of wind-electrical power generation system are highlighted. A number of suggestions are proposed for increasing the share of wind energy in energy balance in Arabic world and in the countries under investigation.

\section{Keywords:}

Wind Energy, Arabic World, Egypt, Yemen, Energy Share

* College of Engineering in Aldawadmi, Shaqra University, Aldawadmi, Kingdom of Saudi Arabia

** Faculty of Engineering, Assiut University, Assiut, Egypt 


\section{Introduction:}

The high demands on fossil fuels result in an increase in the rate of energy consumption by average of 2.0 percent per year from 2003 to 2030 [1-30]. Moreover, the demand ultimately accelerates the depletion of fossil oil resources. This directs the research worldwide into alternative energy sources such as renewable, nuclear, and coal.

The Renewable Energy Sources (RES) are considered the future trendsetter of securing cheap and clean sustained energy supply [1]. The RES started to compete with conventional fuel systems in four main areas; electricity generation, hot water and space heating, transport fuel, and rural (off-grid) energy. The already installed capacities of RES by the end of year 2004 for the electricity generation are shown in Table (1).

Table (1): Installed capacities of RES by end of 2004 [2]

\begin{tabular}{|c|c|}
\hline RET & Existing Capacity \\
\hline Power Generation Sector & 720 \\
\hline Large hydropower & 61 \\
\hline Small hydropower & 48 \\
\hline Wind turbines & 39 \\
\hline Biomass power & 8.9 \\
\hline Geothermal power & 2.2 \\
\hline Solar PV, off grid & 1.8 \\
\hline Solar PV, grid connected & 0.4 \\
\hline Solar thermal power & 0.3 \\
\hline Ocean (tidal) power & 160 \\
\hline Total renewable power capacity(excluding large \\
hydropower)
\end{tabular}

Table (1) indicates that the contribution of RES in the electricity production is only $4.21 \%$. However, this percent is anticipated to escalate in the near future [1-20]. Table(1) show also that the wind energy comes in third place after hydro powers in the end of 2004. By the end of 2020, the wind power outcomes are expected to be around $500 \mathrm{GW}$. Therefore, the wind energy may in the near future be in the first place of RES regarding electricity production [15-30].

This is because; wind energy has matured to a level of development where it is ready to become a generally accepted utility generation technology. Wind-turbine technology has undergone a dramatic transformation during the last 15 years, developing from a fringe science in the 1970s to the wind turbine of the 2000s using the latest in power electronics, aerodynamics, and mechanical drive train designs [1-8].

In the past decades, wind energy had the highest growth rate among other renewable energy sources. This is due to the technological advances in the wind power industry, making this source of energy more reliable and profitable. Nowadays, electricity from 
wind is commercialized and its penetration into the present power systems is increasing. In addition, wind power generation has been gaining acceptance from investors and more wind farms are being built because this industry has become profitable. The cost of energy from wind has dropped to the extent that the price of wind energy is competitive with conventional sources of energy. Also, another key factor of increasing the interest in the wind farms is the climate change. As, the conventional generation of electric power based on burning fossil fuels is one of main contributors to climate change. Moreover, this approach of generating electricity is less efficient, as the overall efficiency of fossil fuel station is less than 50\% [1-53].

This paper presents concise highlighting of wind energy and its evolving from past till now. The focus is on the production of electricity from wind energy, as this is the most widely and prominent application of wind energy. The share of wind energy in electricity production in world is briefly covered. However, more highlight is given to Arabic region. Two-case studies are thoroughly investigated regarding wind energy. The first is about Egypt, while the other is regarding Yemen. In these cases, wind atlases are given showing the promising areas for building wind farms. Also, the technical and economical challenges in the countries under concern are addressed. Finally the future prospection also in these two countries is illustrated.

\section{Wind Energy:}

The wind is one of the sources that had been discovered by the human since the first steps. Utilizing the wind in daily life was dated back to the ancient Egyptians, they used wind to sail the Nile. The ancient Persians created the first windmills to grind grain and pump water. The Dutch used windmills to reclaim their land from the sea by draining wetland. Windmills were first used to generate electricity in North America in the 1800s. This approach continued until the 1930s when the extension of the electric power grid to rural areas brought the decline of demand for electricity generated on-site. The interest in generating electricity from wind renewed again in the second half of the last century. Nowadays, the wind energy supplies around $1.3 \%$ from the total electricity in the world [1-10].

Wind could be simply defined as air in motion. This motion is sporadic, but in most cases the horizontal component of wind flow greatly exceeds the flow of the vertical one. The speed of wind varies from absolute calm to speeds around 380 kilometers per hour. For example, in 1894, strong winds in Nebraska pushed six fully loaded coal cars over 160 kilometers in just over three hours [3-6].

Generally the wind is originated due to the sun. Wind develops as a result of spatial differences in atmospheric pressure. Generally, these differences occur because of uneven absorption of solar radiation at the surface of the Earth, Figure (1) [4]. Wind flow patterns are modified by the earth terrain, bodies of water, and vegetative cover. Wind speed tends to be at its greatest during the daytime when the greatest spatial extremes in atmospheric temperature and pressure exist. For more details regarding the physics of the wind and factors 
affecting its speed/direction/strength, please consulate these references [4-8].

Wind power is one of the most efficient, affordable and inexhaustible. It is pollution-free and cost effective in comparison to coal and gas fired power plants. Advancements in wind energy have been growing rapidly.

Apart from multi-megawatt wind turbines, there is a growing sector within industry: "Residential wind".

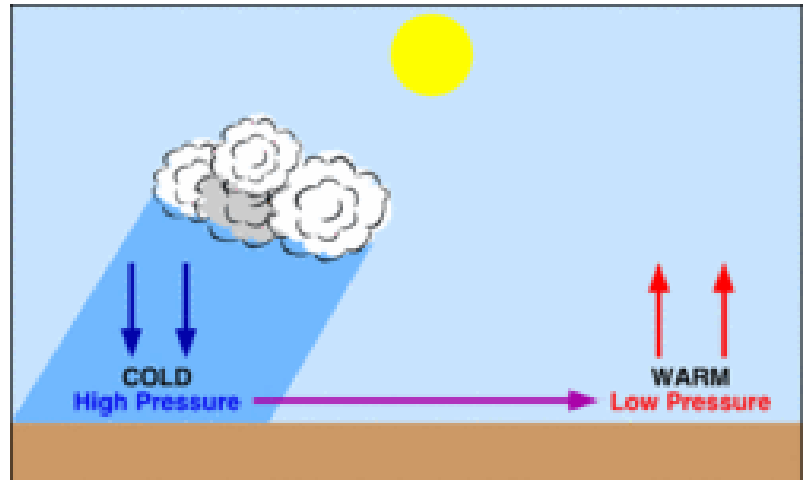

Figure (1): Formation of wind as a result of localized temperature differences [4].

Improved airfoil designs for maximum efficiency at low wind speed; high efficiency direct drive permanent magnet alternators and highly sophisticated controls and inverters are now allowing home owners design off-grid systems. These systems are not only increasing energy independence but also competing with current energy prices and reducing environmental impacts [7-53].

\subsection{Wind Energy Applications:}

As mentioned above that some ancient communities used the wind in a variety of applications, such as sailing in rivers for transporting people and products. However, this application still exists in some primitive communities, and in sea-sports. Another prominent application for the wind particularly in the rural areas is water pumping [7-30].

\subsubsection{Wind Water Pumping :}

Wind mechanical water pumping has been used for centuries for providing clean water for crops and inhabitants. The technology of modern wind water pumpers is relatively simple, the maintenance requirements are modest, and the replacement parts are not difficult to obtain. The wind water pumper is the best option in some circumstances. However, due to the location constrains, the wind water pumpers are often unable to capture the best wind resources. Recently, the trend is to use electric wind water pumping system. This system overcomes the problems with the previous one. In the electric system, the wind energy is turned into electricity then supplied to electric motor that drives a mechanical pump. Wind electric pumping systems allow greater sitting flexibility, higher efficiency of wind energy conversion; increased water output, increased versatility in use of output power, and decreased maintenance and life-cycle costs [7]. This system primarily relies on generating 
electricity from the wind, which will be covered in more details in the following.

\subsubsection{Wind Industrial Applications:}

The number of dedicated industrial applications for wind power continues to grow. Small wind power systems are ideal for applications where storing and shipping fuel is uneconomical or impossible. Wind power is currently being used for the following applications:

- Telecommunications

- Radar

- Pipeline control

- Navigational aids

- Cathodic protection

- Weather stations/seismic monitoring

- Air-traffic control

For more details regarding different applications of wind energy, please consulate the following references [8-13].

\section{Electricity from wind energy:}

Nowadays, the main application of the wind energy is generation of electricity. A typical electric power generation based on wind energy is shown in Figure (2). The essential components are given in this Figure; however different layers of control are hidden, as they are not in the path of the power flow. The system shown in Fig, 2 composed of wind turbine, electric generator, interfacing electronics, transformer and grid.

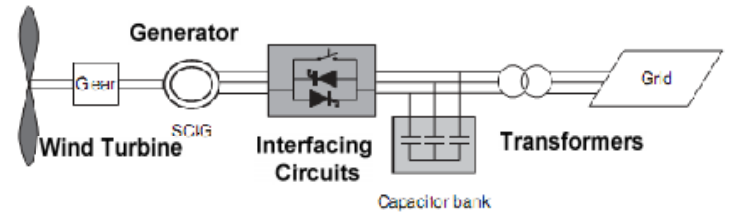

Figure (2): A typical electric power based on wind energy

\subsection{Wind Turbine:}

The wind turbine is the device that converts kinetic energy stored in the wind into mechanical. Wind turbine is prominent feature in the wind electricity generation system. It in general resembles the fan; however, there are different types of the wind turbine. These different types are briefly described below. In general wind turbines are divided by structure into horizontal axis and vertical axis.

\subsubsection{Vertical axis wind turbine:}

The axis of rotation for this type of turbine is vertical. It is the oldest reported wind turbine. The modern vertical axis wind turbine design was devised in 1920 s by a French electrical 
engineer G.J.M. Darrieus [14]. It is normally built with two or three blades. A typical vertical axis wind turbine is shown in Figure (3). Note that the C-shaped rotor blade is formally called a 'troposkien'

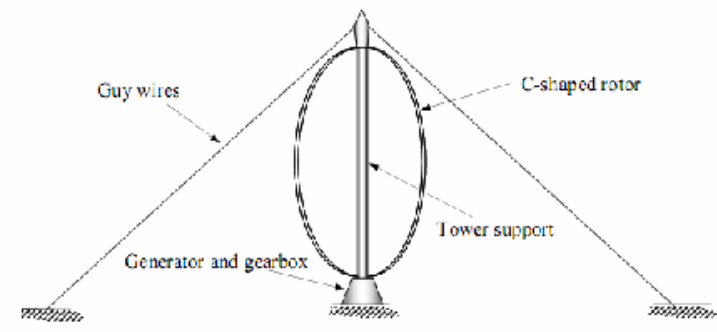

Figure (3):Vertical axis wind turbine

\subsubsection{Horizontal axis wind turbine:}

Horizontal axis wind turbines are those machines in which the axis of rotation is parallel to the direction of the wind. Nowadays, most wind turbines are of the horizontal axis type. Depending on the position of the blades wind turbines are classified into upwind machines and downwind machines as shown in Figure (4). Most of the horizontal axis wind turbines are of the upwind machine type.

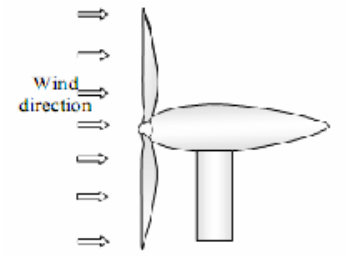

(a) Upwind machine

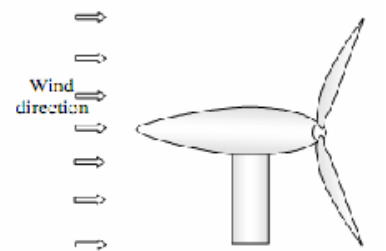

(b) downwind machine

Figure (4) :Horizontal axis wind turbine

The torque in a wind turbine is produced due to the force created as a result of pressure difference on the two sides of each blade of the wind turbine. The pressure in fast moving air is less than in stationary or slow moving air. This principle helps to produce force in an aeroplane or in a wind turbine. To explain the detail of the force created due to the wind, a cross sectional area of the blade of a wind turbine is given in Figure (5). The air traveling from A to B follows two paths. The shape of the upper surface (path 1) results in higher velocity than the lower surface (path 2). This will create a low pressure on path 1 side of the blade. Hence force $\mathrm{F}$, at $90^{\circ}$ to the air flow, will be produced and pushes the blade upwards. This force $\mathrm{F}$ multiplied by the radial distance from the hub at which the force is created gives the torque. 


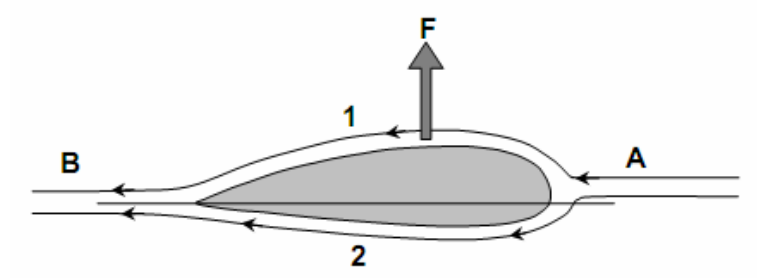

Figure (5): Air flow around cross section of a blade of a wind turbine

Wind turbine technology has improved significantly in the past 20 years. Modern turbines are more reliable, efficient, cost-effective, and the sound of the turbines has been reduced significantly compared to their predecessors. Although many improvements have been made, more work is still needed towards improving wind energy grid penetration, reducing the manufacturing and installation cost, and improving turbine efficiency at all wind speeds. The development of new control strategies to maximize power extraction from the wind and increase turbine efficiency will make wind power generation a more reliable source of energy in the future.

\subsection{Electric Generator:}

The generator is the machine that converts mechanical power supplied by the turbine into electricity. The selection of the generator type is critical in optimizing the wind energy systems. In general, the output characteristics of the wind turbine power do not comply precisely with the generator power; therefore they have to be matched in the most reasonable possible way. The designer primarily selects the generator and the gear box in the wind energy system based on the maximum expected speed of the turbine and taking into the consideration the cubic relationship between the wind speed and the generated power. The correct selection of the generator rated speed is the most crucial part, if it is too low, a significant portion of the wind energy is lost, if it is too high, expensive and unreliable gearbox has to be deployed. The characteristics of the commercially available turbines and generators must be matched to the requirements of the project with regard to cost, efficiency and maximum generated power in an iterative design process [2-4]. The selection of the generator primarily depends on a number of factors related to the energy source such as, the nature of the load, and the speed of the turbine, the maximum expected power, the kind of the operation (stand-alone or connected to the grid), the degree of the interruptibility, and the quality and cost of their output [2-4].

Several generator types have been investigated to be coupled to the rotating wind turbines: DC and AC types. The DC machines are excluded due to their bulky size, high cost and maintenance needs.

The induction generators have promising features for this application; they are rigid, inexpensive, and commercially available. Induction generators generally have outstanding operation; they have very robust construction features, providing natural protection against short-circuits, and have the lowest cost with respect to other generators. Abrupt speed 
changes due to load or primary source changes, as usually expected in wind energy, are easily absorbed by its solid rotor, and any current surge is damped by the magnetization path of its iron core without fear of demagnetization $[4,5]$.

\subsection{Interfacing Circuits:}

The electric power harvest from the wind turbine-generator is not generally in the right format to be pumped directly into grid/ loads, therefore interfacing circuits are usually deployed. These circuits are composed of electronic devices with these controllers.

\subsection{Transformers:}

Generally wind farms are located in remote sites; therefore, the generated electric power after processed should be transmitted over long distances. To optimize the system and maximize the advantages, a transformer should be utilized in the wind farm to step the voltage up, while stepping down the current.

\subsection{Electric power captured from the wind:}

Generally wind farms are located in remote sites; therefore, the generated electric power after processed should be transmitted over long distances. To optimize the system and maximize the advantages, a transformer should be utilized in the wind farm to step the voltage up, while stepping down the current.

\subsection{Electric power captured from the wind:}

The kinetic energy $\mathrm{K}_{\mathrm{E}}$ of the wind is given by,

$\mathrm{K}_{\mathrm{E}}=\frac{\mathrm{mV}^{2}}{2}$

where $\mathrm{m}$ and $\mathrm{V}$ are the mass in $\mathrm{kg}$ and the speed in $\mathrm{m} / \mathrm{sec}$ of the air respectively. Although the kinetic energy of the wind varies with the square of the wind, however, the captured power by the turbine varies with the speed cubic, as shown by

$\mathrm{P}=\mathrm{k} \frac{\rho \mathrm{AV}^{3}}{2}$

$\mathrm{P}, \mathrm{A}, \mathrm{V}, \mathrm{k}$ and $\rho$ are the captured power $(\mathrm{W}), \mathrm{A}$ cross section area of the turbine $\left(\mathrm{m}^{2}\right), \mathrm{V}$ speed of the wind in $\mathrm{m} / \mathrm{s}, \mathrm{k}$ is constant and $\rho$ is the air density $\mathrm{kg} / \mathrm{m}^{3}$ respectively. According to Betz [15], the theoretical maximum power that can be extracted from the wind is:

$\mathrm{P}_{\text {max }}=0.59 \frac{\rho \mathrm{AV}^{3}}{2}$

\section{Economics of wind-based electricity:}

The costs of electrical power generation from wind energy are considered the lowest among the RES. This is shown in Table (2), where the costs of electricity production from different 
RES are summarized as well as the potential for their reduction and trends. These costs are based on the economics of projects excluding subsidies and any other policy incentives and are based on base load operation.

Several countries have achieved relatively high levels of wind power penetration (with large governmental subsides) such as $19 \%$ of stationary electricity production in Denmark, $13 \%$ in Spain and Portugal, and 7\% in Germany and the Republic of Ireland in 2008. As of May 2009,80 countries are using wind power on commercial basis [12-16].

Table (2): Costs and characteristics of renewable technologies [3]

\begin{tabular}{|l|l|l|l|}
\hline Technology & $\begin{array}{l}\text { Typical } \\
\text { Characteristics }\end{array}$ & $\begin{array}{l}\text { Typical } \\
\text { Energy } \\
\text { Costs } \\
\text { (cents/kWh) }\end{array}$ & $\begin{array}{l}\text { Cost Trends and Potential for Cost } \\
\text { Reduction }\end{array}$ \\
\hline $\begin{array}{l}\text { Large } \\
\text { hydro }\end{array}$ & $\begin{array}{l}\text { Plant size: } \\
10-18,000 \mathrm{MW}\end{array}$ & $3-4$ & Stable. \\
\hline $\begin{array}{l}\text { Small } \\
\text { hydro }\end{array}$ & $\begin{array}{l}\text { Plant size: } \\
1-10 \mathrm{MW}\end{array}$ & $4-7$ & Stable. \\
\hline $\begin{array}{l}\text { On-shore } \\
\text { wind }\end{array}$ & $\begin{array}{l}\text { Turbine size: } \\
\text { MW } 1-3 \\
\text { Blade diameter }\end{array}$ & $: 4-6$ & $\begin{array}{l}\text { Costs have declined by 12-18\% with each } \\
\text { doubling of global capacity. Costs are } \\
\text { now half those of 1990. Turbine size has } \\
\text { increased from 600-800 kW a decade } \\
\text { ago. Future reductions from site } \\
\text { optimization, improved blade/generator } \\
\text { design, and electronics }\end{array}$ \\
\hline $\begin{array}{l}\text { Off-shore } \\
\text { wind }\end{array}$ & $\begin{array}{l}\text { Turbine size: } \\
1.5-5\end{array}$ & $\begin{array}{l}\text { MW } \\
\text { Blade diameter } \\
70-125 \mathrm{~m}\end{array}$ & $\begin{array}{l}\text { Market still small. Future cost reductions } \\
\text { due to market maturity and technology } \\
\text { improvement. }\end{array}$ \\
\hline $\begin{array}{l}\text { Rooftop } \\
\text { solar PV }\end{array}$ & $\begin{array}{l}\text { Peak capacity: } \\
2-5 \mathrm{~kW}\end{array}$ & $20-40$ & $\begin{array}{l}\text { Continuing declines due to lower solar PV } \\
\text { module costs and improvements in } \\
\text { inverters and balance-of-system } \\
\text { components. }\end{array}$ \\
\hline $\begin{array}{l}\text { Solar } \\
\text { thermal } \\
\text { Power } \\
\text { (CSP) }\end{array}$ & $\begin{array}{l}\text { Plant size: } 1- \\
100 \text { MW } \\
\text { Type: tower, } \\
\text { dish, trough }\end{array}$ & $\begin{array}{l}\text { Costs have fallen from about 44 } \\
\text { cents/kWh for the first plants in the 1980s. } \\
\text { Future reductions due to scale and } \\
\text { technology. } \\
\text { (trough) }\end{array}$ \\
\hline
\end{tabular}


Giga watts (GW), as shown in Figure (6) [16-17].

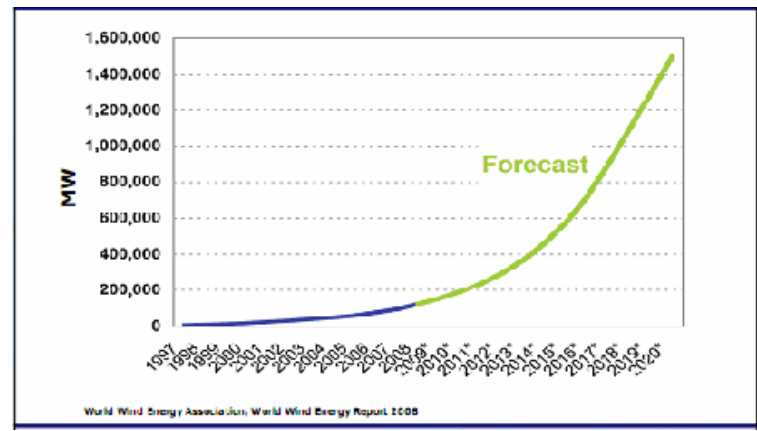

Figure (6): Cumulative Installed Wind Power Capacity (MW) Year 1997/ 2020 [17]

Figure (6) Shows that the commercial application of the wind in generating electricity begun in the end of the last century. Since that, the installed capacity is in exponential increase. For example, the forecasted capacity of wind based electricity in 2020 is around 8 folds that in 2010. The percentage of sharing of different counties in wind based electricity in 2009 is shown in Figure (7).

Figure (7) shows that United States of America (USA) has a great share of wind based electricity, and then China comes in the second place. Both China and USA possess around $60 \%$ of total capacity of the world wind farm.

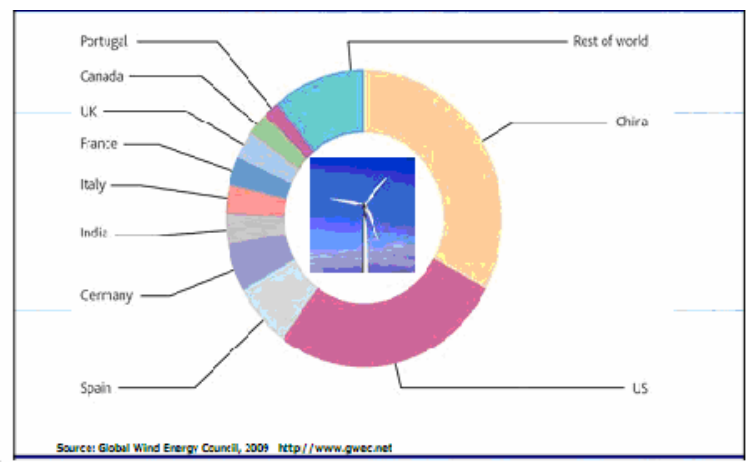

Figure (7): Top ten powers new installed capacity 2009[19]

The wind-based electricity, as mentioned before, is considered to be mature technology. It has highest penetration rates compared to the electricity obtained from other RES. The reported literature [18] shows that worldwide capacity reached 159'213 MW, out of which 38 '312 MW were added in 2009. Also, the growth rate of the wind power is the highest, $31.7 \%$ among other RES. All wind turbines installed by the end of 2009 worldwide are generating $340 \mathrm{TWh}$ per annum, equivalent to the total electricity demand of Italy, the seventh largest economy of the world, and equaling $2 \%$ of global electricity consumption [18-53].

The wind industry nowadays is attracting much intension particularly from private sectors, as it had a turnover of 50 billion $€$ by the end of 2009 . This has the advantage of creating more jobs, which increases the stability and improves the possibility of the life for mankind. For 
example, by the end of 2009, 0.5E6 person worldwide are being employed in the wind industry. Moreover, it is anticipated that more than 1 million additional job would offered in the field of wind industry by 2012. This number also is forecasted to be increase by 5 times by 2020 [40-53].

On the countries basis as mentioned before, the USA maintained its number one position in terms of total installed capacity and China became number two in total capacity, only slightly ahead of Germany, both of them have around 26000 Megawatt of wind capacity installed. China continued its role as the locomotive of the international wind industry and added 13'800 MW within one year - as the biggest market for new turbines -, more than doubling the installations for the fourth year in a row.

On the continental base, Asia accounted for the largest share of new installations (40, $4 \%$ ), followed by North America (28, $4 \%$ ) and Europe fell back to the third place (27,3\%). Latin America showed encouraging growth and more than doubled its installations, mainly due to Brazil and Mexico.

\section{Wind-based electricity in Arabic world}

Unfortunately, the contribution of the Arabic countries in installed capacity of wind farm is below $1 \%$ of that of worldwide, although the majority of these countries have promising environmental conditions for installing wind farm and they suffer from deficiency in the energy resources. Figure (8) shows the wind altas for the world. The average speed for almost whole Arabic countries is more than $6 \mathrm{~m} / \mathrm{sec}$.

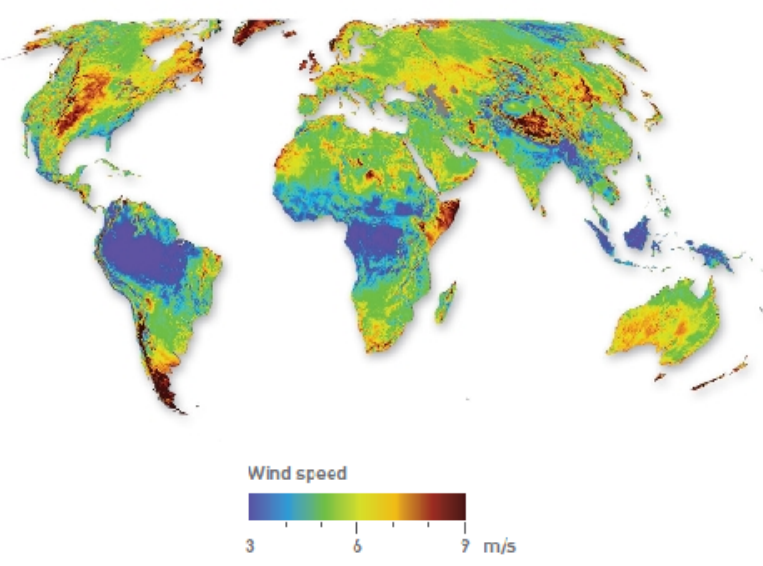

Figure (8):Wind Altas for the world [20]

However, recently some Arabic countries start to realize the economical/environmental advantages of wind based electricity. For example, Tunisia is equally determined to reduce the use of fossil energy and replace it by wind and solar energies. By 2016, Tunisia wants to cut its consumption of fossil energy by 22 percent and replace it by wind turbines and solar power plants.

Egypt possesses a huge potential for wind power generation along the Red Sea. Until very recently this was not be utilized. By 2020, 12\% of Egypt electricity need would be supplied 
by the wind as the government planned. To achieve that, the wind capacity is to be expanded to $7 \mathrm{GW}$ compared to $1 \mathrm{GW}$ in 2010 [20].

Other Arabic countries adopted the same strategy as Egypt and Tunisia, and elaborate plans are put into action, such as:

- New wind farms being installed, and wind atlases being developed or updated in Egypt, Jordan, Morocco, Saudi Arabia, Syria, Tunisia, and UAE.

- Research and development and pilot projects are under going in Egypt, Jordan, Saudi Arabia, and Syria.

- Further consolidation and continuation of the Renewable Energy Promotion Mechanism (REPM) initiated in 1999 in the Economic and Social Commission for Western Asia (ESCWA) region are carried out.

Two-case studies are investigated below regarding wind energy. The first is about Egypt, while the other is about Yemen. In these cases, wind atlases are given showing the promising areas for building wind farms. Also, the technical and economical challenges in the countries under concern are addressed. Finally the future prospection also in these two countries is illustrated.

\subsection{Case Study-1 Electricity from Wind in Egypt:}

Egypt geographically is located between $30^{\circ} 06 \mathrm{~N}$ latitude and $31^{\circ} 25 \mathrm{E}$ longitude at the north east of Africa, while semi-desert of Sini located in north-west of Asia. Egypt has a strategic location, as it the ties Africa and Asia up. Northern coast of Egypt extends over 600km on Mediterranean Sea, while the east coast extends over 600km along the Red sea see Figure (9). The country is characterized by plain deserts, east and west deserts, and rugged foothills mountains particularly in the areas of Red sea and Sini [20-30].

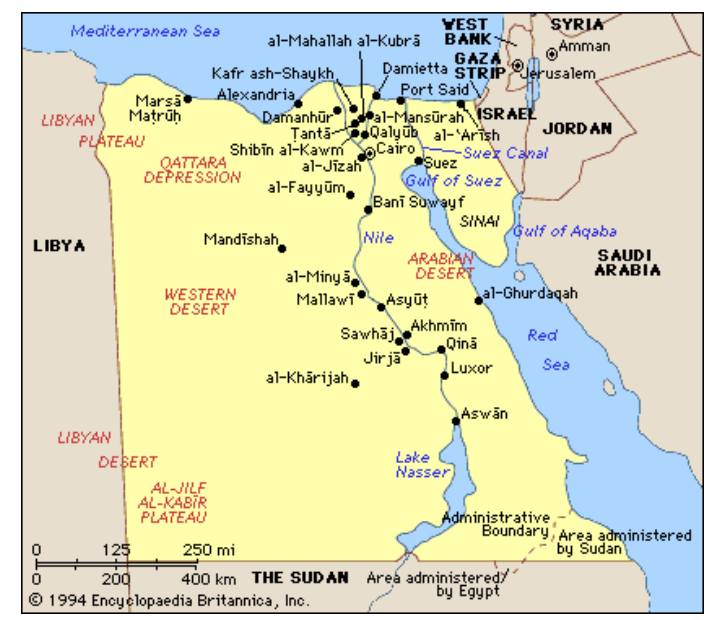

Figure (9): Map topography of Egypt [20]

\subsection{1: Profile energy}

Egypt has limited resources regarding the energy, the different types of daily consumed 
energies are shown in Figure (10). Almost all of Egypt 3.3 quadrillion Btu of energy consumption in 2007 was met by oil, 51\%, and natural gas, 42\%, Figure (10) [21]. Oil is mostly utilized for the transportation sector; however, recently due to the development of Compressed Natural Gas (CNG) infrastructure, the transportation sector is expected to grow. There is coal in Egypt, however it accounts only for 1\% from the energy consumption. Hydro power is mainly extracted from the dams on the Nile in the Upper Egypt provinces and used for generating electricity [20-22].

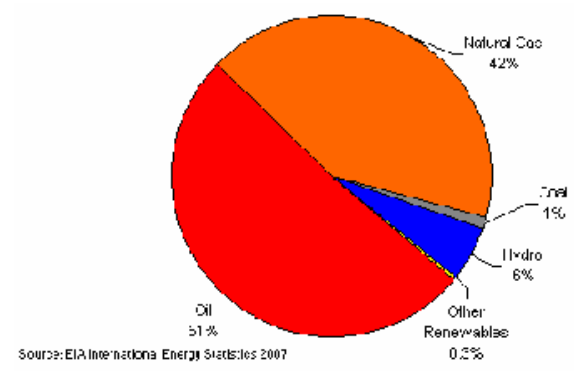

Figure (10): Total energy consumption in Egypt, by type (2007) [21]

Decreases in oil production have been offset by the rapid development of the natural gas sector for both domestic consumption and export. Over the past decade, Egypt has become a significant natural gas producer and a strategic source for European natural gas. Egypt currently has a pipeline network for exports to southern Europe and Eastern Mediterranean countries in addition to liquefied natural gas (LNG) exports to Europe, Asia and the Americas. However, increasing domestic demand for natural gas has led the government to stall natural gas export expansion plans [20-28].

In terms of electricity generation, natural gas represents over 80 percent of the total mix, the remainder being met mostly by hydroelectricity. Plans are underway to further expand electricity generation capacity by utilizing the country vast wind and solar resources and also through the development of a nuclear power station scheduled for 2015.

Short notes about major energy types in Egypt are given in the following.

\subsubsection{Oil:}

According to estimate of the Oil and Gas Journal in January 2010, Egypt has proven oil reserves stand at 3.7 billion barrels. In 2009, Egypt has total oil production averaged 685,000 barrels per day (bbl/d), of which an approximately 440,000 bbl/d was crude oil. Despite discoveries and enhanced oil recovery techniques at mature fields, crude oil production is declining. At the same time, new natural gas field production has led to increases in the production of natural gas liquids and lease condensates which have offset some of the declines in total oil liquids production. Oil consumption is slightly higher than production estimates at 710,000 bbl/c and, according to Review of Oil Market Trends (APS), the country registers a small volume of net oil imports, Figure (11). These imports are, in part, the result of Egypt refining capacity being larger than oil production levels. Oil imports are expected to 
domestic demand growth.

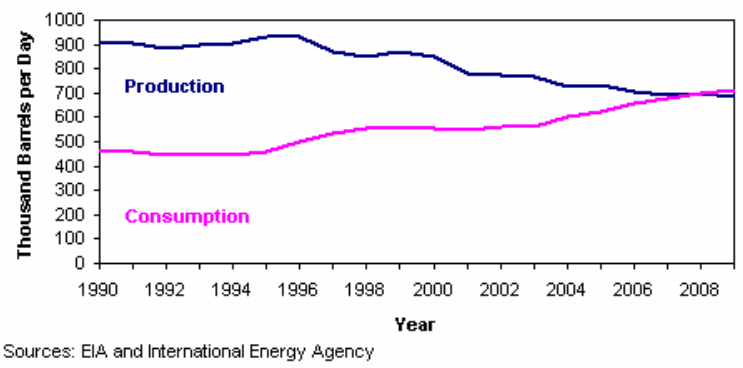

Figure (11): Total Oil production and consumption of Egypt 1990 - 2009

\subsubsection{Gas:}

Due to major recent discoveries, natural gas is likely to be the primary growth engine of energy sector in Egypt for the foreseeable future. Egypt has natural gas sector is expanding rapidly with production having nearly tripled between 1998 and 2008. In 2008, Egypt produced roughly 1.9 trillion cubic feet (Tcf) and consumed 1.1 Tcf, Figure (12).

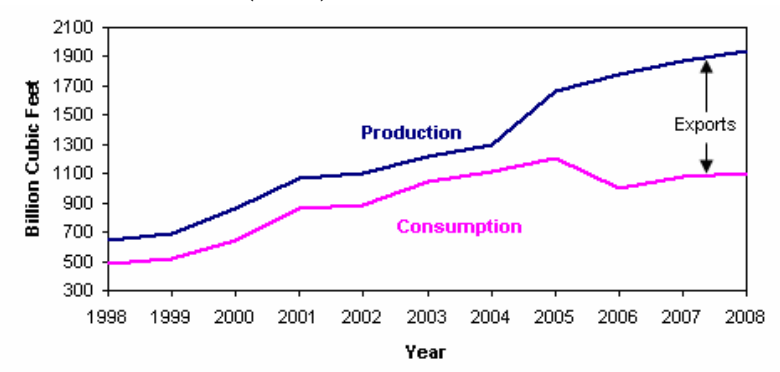

Figure (12): Natural gas production and consumption of Egypt 1990 - 2009

According to the Oil and Gas Journal estimate, Egypt has gas reserves stand at 58.5 Tcf, the third highest in Africa after Nigeria (185 Tcf) and Algeria (159 Tcf). With the ongoing expansion of the Arab Gas Pipeline, and liquefied natural gas (LNG) facilities, Egypt will continue to be an important supplier of natural gas to Europe and the Mediterranean region. According to Cedigaz, the electricity sector has the largest share of natural gas consumption at 54 percent followed by industrial sector with 29 percent.

Egypt has highest population amongst Arabic countries, the recent estimations of the population are nearly 85million. Egypt is considered to be first Arabic country to use renewable energy sources in terms of hydraulic power (High dam in Aswan, and Assna's dam).

In order to supply the increased energy demand in Egypt, the government decided to build five nuclear stations. The preliminary phases are under progress. Moreover, the government set a strategic plan for increasing the share of RES in energy market in Egypt, they set that by 2020 around 20\% from the electricity in Egypt would be supplied from RES (12\% from wind and $8 \%$ from solar-based systems).

Egypt enjoys an excellent wind profile. This is shown in wind atlas, Figure (13). The Wind Atlas for Egypt is one of the first - and the most comprehensive - numerical wind atlases 
ever established. The wind resource over an area of more than one million square kilometers, much of which consists of mountains and remote desert tracts, has been determined by two independent methods: a traditional wind atlas based on observations from more than 30 stations all over Egypt, and a numerical wind atlas based on long-term reanalysis data and a mesoscale model. The wind atlas allows for wind resource assessment and sitting anywhere in Egypt, and further provides bankable resource estimates in the most promising regions.

The wind speeds shown in Figure (13) are estimated at 10m height; however, as the height increases, the wind speeds soar. This is shown in Table (3), where the average wind speeds at $25 \mathrm{~m}$ height for some promising sites in Egypt are given.

Table (3) shows that El Zafarana is promising site regarding the generation of the electricity. This fact was realized by government since the last two decades; they established the first wind farm of in the Arabic world in this site in co-operation with Germany.

The electricity wind-based in Egypt is forecasted to reach by 2012 to 850MW around 3\% of the electricity consumption, Figure (14). As mentioned above the country is determined to reach $12 \%$ by 2020 .

In order to effectively meet these goals, Egypt is not only committed to refine and strengthen the legal and regulatory framework governing wind power in Egypt, but also to provide the necessary reliable background information on the geographical variation and magnitude of the Egyptian wind resource.

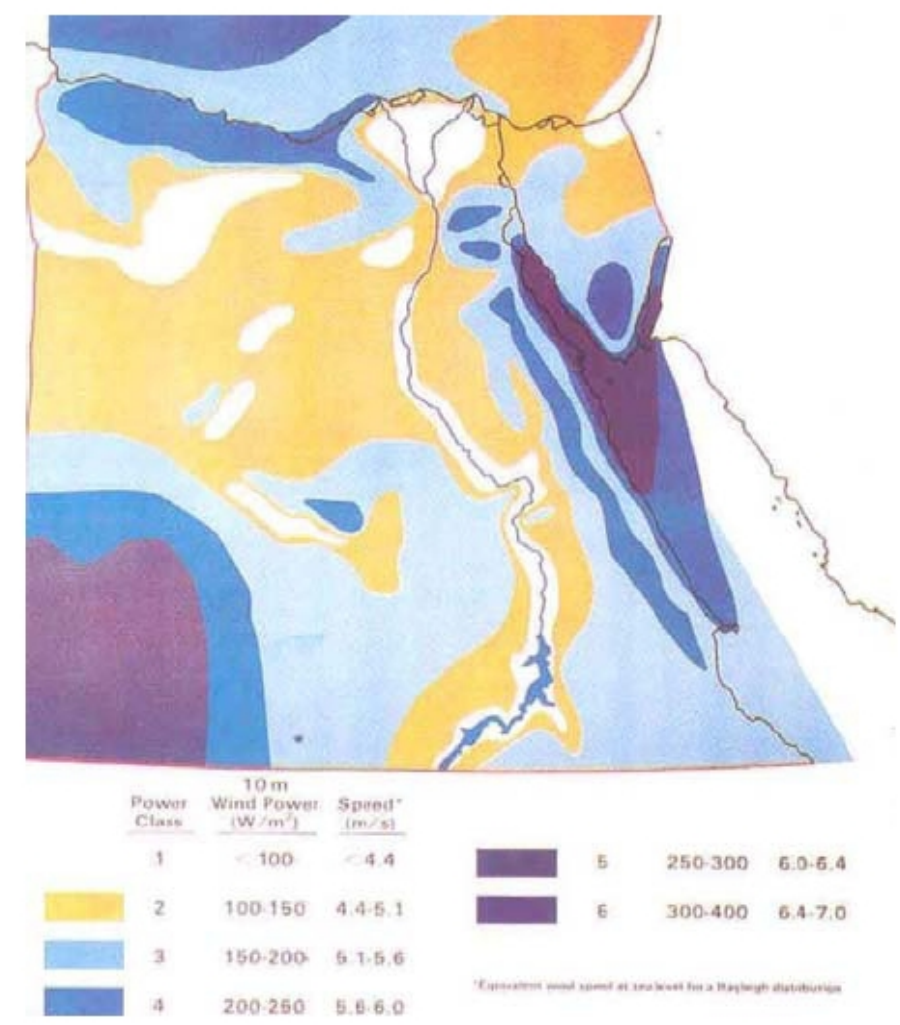

Figure (13): Wind atlas of Egypt 
Table (3): The average wind speed at $25 \mathrm{~m}$ height

\begin{tabular}{ll}
\hline Region & Average wind speed $(\mathrm{m} / \mathrm{s})$ \\
Ras Sedr & 7.5 \\
Abu Aldarag & 8.8 \\
Zafarana (North) & 9.2 \\
Zafarana & 9.0 \\
Zafarana (West) & 7.5 \\
St. Paul & 8.4 \\
Ras Ghareb & 10.0 \\
El Tour & 5.6 \\
El - Zayt Gulf (North) & 10.4 \\
El - Zayt Gulf (North-West) & 10.5 \\
El - Zayt Gulf & 10.3 \\
El - Zayt Gulf (South-West) & 10.8 \\
\hline Hurgda & 6.7 \\
\hline
\end{tabular}

A milestone in this development is the wind Atlas for Egypt which was published recently by the New and Renewable Energy Authority (NREA) and the Egyptian Meteorological Authority (EMA) in Cairo, in cooperation with Riso National Laboratory [23], Figure (14.) Moreover, the country established a new agency that concern with RES under name of the New and Renewable Energy Authority (NREA). It was founded in 1986, with the aim to boost solar, biomass and wind power production.

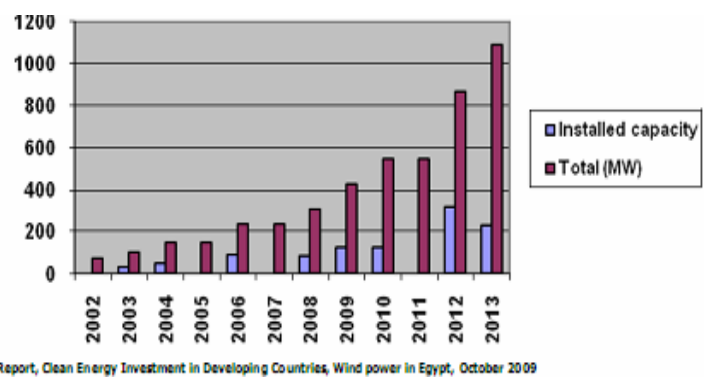

(A)

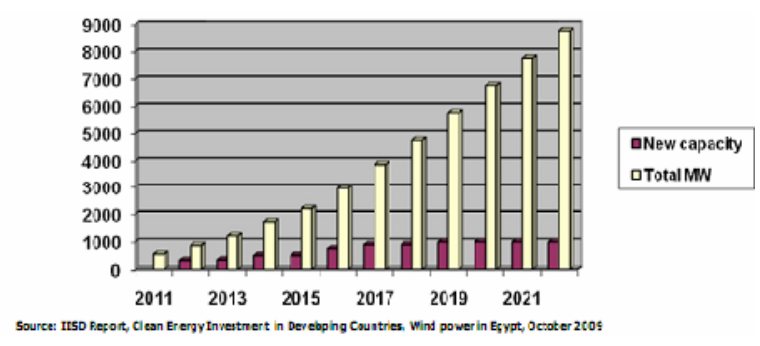

(B)

Figure (14): Egypt wind power, A-(2002 - 2013) B-(2011 - 2021) [23] 
Since 2001 a series of linked wind farms have been built at Zafarana with the support of the Danish, German and Spanish governments. Their total installed capacity has now reached 360 MW. The used wind turbines in Zafarana site came from the Danish Vestas, German Nordex and Spanish Gamesa companies. Their installation has been carried out under the banner of the Egyptian New and Renewable Energy Agency (NREA).The most recent development is a 240 MW phase being constructed with the support of the Danish and Japanese government aid agencies. Half of this is due for commissioning by the end of 2009 . Eventually the total capacity at Zafarana will reach $545 \mathrm{MW}$.

The Zafarana project, which was a major step towards the large-scale deployment of wind power in Egypt, has contributed to technology transfer in terms of providing operational experience in wind power plant operation, as well as local assembly of the turbines. Based on this experience the Egyptian government is now opening up a larger area of 656 square kilometers at El-Zayt, south of Zafarana. With a potential for 3,000 MW of wind power capacity, this will involve private sector investment for the first.

\subsubsection{Zafarana Wind farms:}

In the south east of Cairo by $220 \mathrm{~km}$, has been selected to host the first large wind park. The site has been specified as one of the best all over the world and the largest wind farm in Africa and Middle East, with excellent wind characteristics: stable profile, relatively small variations and plain extended territories. An area of $156 \mathrm{~km}^{2}$ has been allocated in north of Zafarana to implement wind farms, Figure (15).

The location of the Zafarana as mentioned has most promising characteristics: $9.5 \mathrm{~m} / \mathrm{sec}$ average wind speed, low turbulence and high capacity factor. Now in service there is a $255 \mathrm{WM}$ wind farm, around $30 \%$ from this station is locally manufactured. It is worth to mention the different stages, Figure (16), of this plant here:

Zafarana-1: $30 \mathrm{MW}, 50$ Nordex $600 \mathrm{KW}$ turbines in cooperation with DANIDA was on in service since April. 2001.

Zafarana-2: 33 MW 55 Nordex $600 \mathrm{KW}$ turbines in cooperation with $\mathrm{KFW}$ is operating since May 2001.

Zafarana-3: $30 \mathrm{MW}, 46$ Vestas $600 \mathrm{KW}$ turbines in cooperation with KFW was installed on November 2003.

Zafarana-4: $47 \mathrm{MW}, 71$ Vestas $600 \mathrm{KW}$ turbines in cooperation with KFW is running since June 2004.

Zafarana-5: $85 \mathrm{MW} 100$ Gamesa G52 turbines $850 \mathrm{KW}$ each in cooperation with Spain; this stage was in service since the end of September 2006 [23].

Zafarana-6:120 MW, in cooperation with Japanese was installed at the the end of Sep. 2007.

Zafarana-7: 120 MW, in cooperation with Japanese is running since Apr. 2010 [24]. This is the most recent stage. 


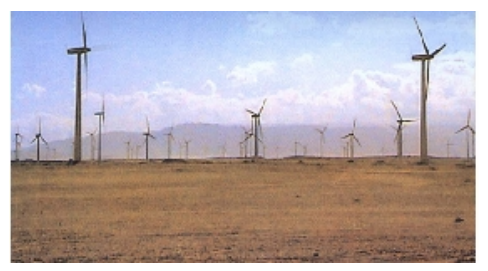

Figure (15): Zafarana wind farm [25]

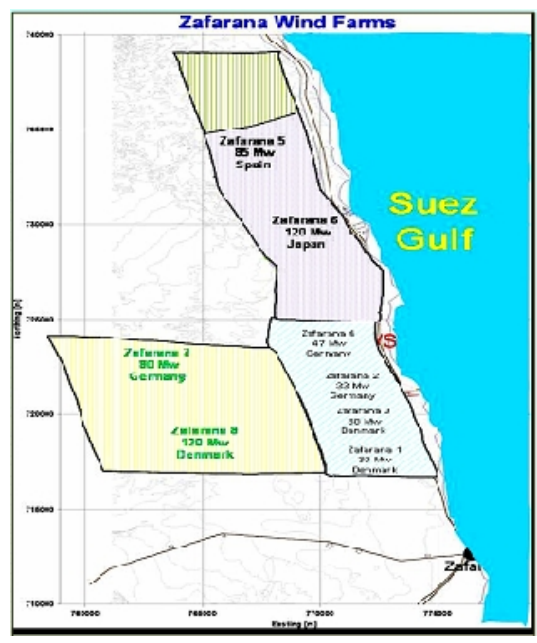

Figure (16): Zafarana wind farms plan [25]

A pilot projects were carried out in other locations rather than Zafarana, from these places are Hurghada and Ras Ghareb. A brief review for the different projects regarding wind farms in these sites is given in the following

\subsubsection{Hurghada wind farms:}

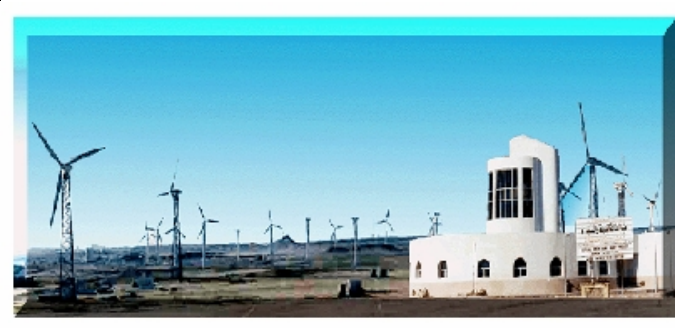

Figure (17): WETC in Hurgada [25]

In Hurghada south east Cairo, Wind Energy Technology Centre(WETC) was established in association with Danish collaborators. The centre was act as a test centre for wind turbines in order to optimize the design and performance of this technology. Also, this centre provides training for the manpower for running the wind farms and carrying out the schedule and unscheduled maintenance. However, research programs are still in the initialization phase. The WETC is composed from the following, Figure (17):

- Wind turbine test facility equipped similarly to the test station for wind turbines at Riso National Laboratory in Denmark. 
- Central WETC building housing management, offices, test room, classroom, meeting room and a control room for the central wind farm monitoring and control system (CMCS).

- Mechanical and an electrical workshop.

- Wind farm of 4 x $300 \mathrm{~kW}$ Nordtank wind turbines (to be expanded to $6 \times 300 \mathrm{~kW}$ after the completion of the testing of the $2 \times 300 \mathrm{~kW}$ wind turbines being presently being tested at the test facility).

- Wind farm of $22 \times 100 \mathrm{~kW}$ Wincon wind turbines.

- Wind farm of $10 \times 100 \mathrm{~kW}$ Ventis wind turbines.

As a separate facility in the compound, a test center for small scale wind systems of $5-25 \mathrm{~kW}$ for isolated applications is established. A sketch of the Hurghada WETC site with indication of all building facilities, wind farms and the wind turbine test beds.

\subsubsection{Ras Ghareb Wind Farms:}

The first wind energy demonstration wind farm was established in Ras Ghareb on the Red Sea coast, with $400 \mathrm{~kW}$ capacity. Recently, a 5.2 MW wind farm in nearby site is operating successfully containing different designs and sizes of wind turbines, 100-300KW. The wind farm is connected to the local electricity grid of the city.

Wind farms Also, are under establishing in other sites as Gabel El Zeit in Suez province as well as the previous mentioned locations. For more details regarding the current and future projects in wind-based electricity in Egypt, please consulate the following references [33-36].

\subsubsection{Wind Technical/economical Challenges in Egypt:}

Egypt as mentioned has tremendous potential of wind energy; also the people are determined to increase the sharing of wind energy in the energy balance. However, there are some technical/economical challenges in Egypt.

- The lack of public awareness regarding the renewable energy sources in general, and wind energy in particular.

- Recently, there is interest in research related to renewable energy sources/wind energy in research institutions and universities; however these research groups are scattered and mainly has limited resource of fund, which reduce their capability of addressing the technical/economical problems facing wind energy in Egypt.

- There is obvious deficiency in the local technology related to the wind energy in Egypt; also there are shortages in trained engineers and technicians for design, construction, installation and maintenance of wind farm in Egypt.

- The promising wind sites generally are located in rural areas; these areas still require more intention in terms of developing robust infrastructure and building tough grids for connection with the whole country.

- Until recently, the intention regarding potential of wind energy in Egypt was not 
considered seriously, however, now there are strategic plans regarding the optimization of wind energy in Egypt. Still, the regulatory rules and reasonable budgetary support have to be developed or enhanced.

This paper proposes the following solutions for the mentioned constrains regarding wind energy in Egypt

1. The public awareness regarding wind energy can be enhanced by:

- Directed media campaigns about the advantages of RES, and the shortages of fossil fuels.

- Introducing curriculums starting of an elementary school that put some focus on the wind energy, and show the significant potential of Egypt regarding this energy.

- Advising competition between the young people ( students in pre-university and in the university stage) about designing developing, and fabricating RES systems that could solve personally or community problems. For example, design a mobile charger that use photovoltaic.

2. The research related wind energy could be productive by,

- Distributing the fund from funding agency as STDF vertically and not horizontally.

- Establishing national scientific societies, as the international ones that focus on one type of RES. Moreover, these societies should not have class or geographically limitation.

- Encouraging the young researchers for carrying out researches in the areas related to wind energy. As, this class has the passion and determination of exploring innovative techniques and schemes.

3. The wind-based related local technology and manpower could be resolved by,

- Encouraging the industries related to this technology by fully/partially removing the taxes and other related expenses, at least for given years until they could be competitors for their foreign corresponders.

- Developing wind-based technology curriculums in industrial schools and engineering faculties for graduating the skillful technician/engineers. Also, direct the education in the sites nearby the wind farm for developing and supplying these locations by their needs regarding manpower.

4. The wind sites could be developed by :

- Encouraging the youth for working and settling in nearby sites for wind farms. This has mutual benefits: developing the wind sites, and reducing the crowdness in the capital and major cities.

- Developing robust highways that connect these location to the country

- Developing substation for connecting the wind farms outcomes to the national grid.

\subsection{Case Study-2 Electricity from Wind in Yemen:}

Geographically, Yemen is situated between $13 \mathrm{~N}-16 \mathrm{~N}$ latitude and 43.2-53.2 longitude at the 
south west of Asia. Yemen is surrounded by the Red sea from the west and by the Indian Ocean from the south. The country consists of three major zones: coastal, rugged foothills and mountains, Figure (18).

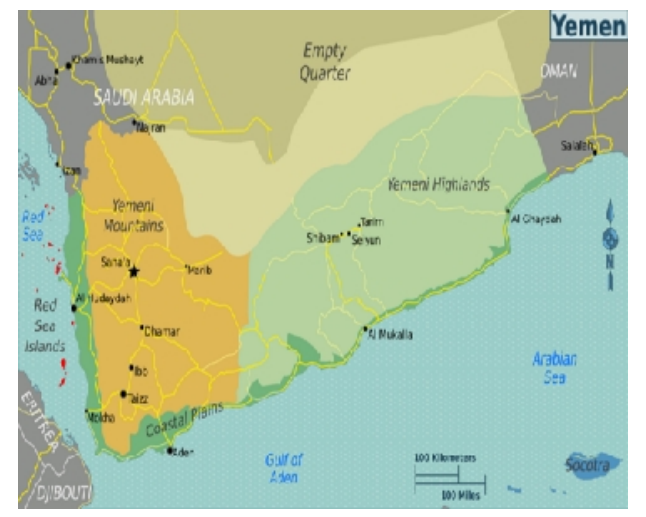

Figure (18): Map topography of Yemen

Since1990 a number of occasions have led to a serious set back of the national economy. The government of Yemen has committed economical reforms, which hopefully would lead to further economical stability and further economical recovery. Energy sector is one of the key elements of mentioned reforms [25].

\subsubsection{Energy Profile:}

Yemen has limited resources regarding energy; for example Figure (19) shows the types of energy used in the daily activities.

Figure (19) shows that the fuel used in rural areas are mainly kerosene and gas for lighting; they may constitute $16 \%$ to $18 \%$ of the total consumed energy in the country. This fact means that majority of the population (rural) uses much less energy than minority (urban). Figs. 18 and 19 express a revealing fact that no contribution of RES in energy balance in Yemen in spite of their high potentials.

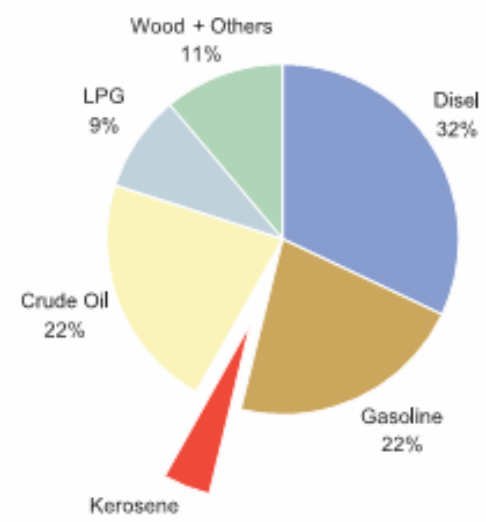

Figure (19): Fuel types in Yemen 2009[26] 
Monthly energy consumption in 2009 in Yemen is shown in Figure (20), where the total consumption is 402,360 TOE.

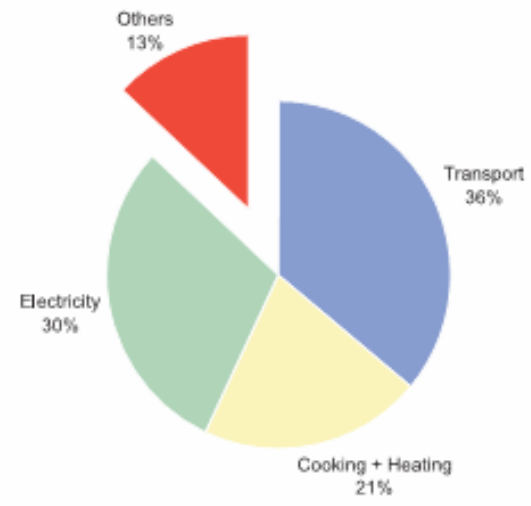

Figure (20):Energy balance monthly [26]

Figure (20) shows that transport sector is the major sink for the energy in Yemen. It is worth to mention, that transport sector involves only vehicles that transport people and products, there is no trains or electric based traction in Yemen.

The electricity production consumes around 30\% of the energy; and most of generation stations are fossil fuels based.

The major energy types in Yemen are oil and gas; a brief for each type is given in the following.

\subsubsection{Oil:}

Oil was discovered in 1984. The total production of Yemen now has reached an average of $439,000 \mathrm{bpd}$. $50 \%$ of which is produced in Al- Masila and the other $50 \%$ is produced in the rest fields.

\section{$\underline{\text { 5.2.1.2Gas }}$}

Natural gas was found in different places in Yemen. The reserve of the gas was estimated recently up to 14.173 Trillion cubic feet. Apparently, Yemen has significant deposits of gas but these reserves have not been developed or effectively utilized due to the absence of appropriate infrastructure and the inability of the government to decide on the most economic options for the gas. Now 42152 Trillion per month of Liquefied petroleum gas (LPG) are currently produced. This amount of production was reached due to participation of private sector in building bottling plants in different locations of the country and distribution of gas bottles. Actually LPG bottles are available now everywhere in the country. More than $80 \%$ of national market is covered.

Although Yemen has a considerable reserve of the gas, however, this was expected to last around 15 to 30 years. Thus, the country should search for alternative energy option to secure 
the requirements of the citizens regarding the energy and to maintain the continuation of the reforms.

\subsubsection{Wind energy Potentials}

Yemen has high potentials of renewable energy sources, namely: solar, wind and geothermal. However, the wind is the most promising.

Yemen has a long coastal strip of over $2500 \mathrm{kms}$ with a width of 30-60 kms along the Red Sea, Gulf of Aden, and the Arabian Sea. Average annual wind speeds measured at $10 \mathrm{~m}$ height exceed $8 \mathrm{~m} / \mathrm{s}$ at most of the coastal sites. There is good potential for wind energy at sites on the coastal strip, in addition to the offshore area. There is also great wind energy on Yemeni islands and inland hills and mountains [27]. Some studies [27, 32] have reported that the wind speed is relatively large at high altitudes and coastal areas. Yemen has a unique geographic location. It has a long coastline and plenty of high altitudes. Due to all these characteristics, Yemen is a perfect place for generating energy from the wind. Yemen possesses promising wind energy potential. However, the wind energy has not yet been studied seriously in though there are many factors encourage using of wind technologies, for example [33]

- Shattered village and houses in different regions of the country, which creates a burden on the national grid for fulfilling the requirements of these isolated places.

- The obvious deficiency in the energy resources in Yemen, and the short life span of oil and gas, which the country currently depend on

- The plan of the government for reforming the coast areas; these projects require electric energy, which could only be provided through wind energy.

- Availability of funds located for rural electrification. [33]. It is worth to mention here that there are some individual activities regarding wind energy such as:

- An experimental wind turbine is installed in Al-Mukha by PEC.

- A Feasibility study of wind farm is being financed by Germany government.

- The national television corporation uses a variety of RES as alternative source for electricity for supplying transmission stations.

These examples as mentioned are on individual base, and cannot represent national trend. Yemen has a number of obstacle that handier the adoption of wind energy

1. Market: Energy market in Yemen has poor market infrastructure; and high investment requirements are necessary to push the cart of wind energy in particular and RES in general.

2. Economics and finance: These barriers could be classified as the high investment risk and capital cost, lack of access to capital and financial bodies.

3. Institutional Barriers: Apparently the institutional barriers are the most important ones to be overcome. These are: lack of institutional framework, lack of institutions and mechanism, lack of regulatory and legal frameworks, lack of coordination and involvement of stakeholders, lack of R \& D culture, lack of private sector participation, 
lack of professional institutions.

4. Technical Barriers: Technical Barriers are: lack of standards, codes and certification, lack of skilled personnel.

5. Social and other Barriers.

We propose a number of solutions for the above constraints, these are:

1. To overcome the deficiency of energy market in Yemen, a robust infrastructure should be established that connect the location of RES to the country. Usually, the location of RES are in rural and remote areas, however, the robust infrastructure has additional benefit that creating new cities and redistribution the population over wide areas of the country, which secure the national securities and reduce the crowdness and all related crimes.

2. The deficiency of lack of institutional framework could be resolved by

a. Adopting national trend of increasing the share of RES in energy market in Yemen by introducing educational materials related to RES in different education stages starting from elementary schools.

b. Developing an efficient mechanism for coordination between different stakeholders and concerned parties.

3. The constraints of high investment cost can be attacked by

a. Initiating a communication program aiming to attract international agencies (lenders and donors).

b. Inviting the private sectors for any corporation scheme that achieves mutual benefits for the stakeholders and the people such as $\mathrm{P} \& \mathrm{O}$.

c. An additional helping factor is the local government contribution which exceeds nine million US Dollars per year may partially be allocated for this purpose too.

4. The lack of legal framework could be resolved by adopting legislations that regulate the relations and functions of different stakeholders. These legislations should be put into action after being approved by the suitable institutional body.

5. The handicap of absence of specialized financing agencies could be overcome by establishing a specialized financial agency similar to Agricultural Credit Bank. However, such agency should have more sophisticated procedure and functions due to the special role.

6. The lack of public awareness could be resolved by initiating a governmental program aiming for public awareness about renewable energy sources technologies and their advantages and benefits.

7. The lack of the regional and international cooperation could be addressed be advertising the mutual benefits of wind based electricity regarding the reduced running cost. It is worth to mention that recently, there are many international and regional agencies have initiated cooperation projects with Yemen government. These are ESCWA, UNDP, World Bank, GTZ, Dutch Government, European Union, Jordanian Government, Japan and Egypt. However, there is a lack of coordination either inside Yemen or between 
Yemen these agencies / between these agencies themselves. Other International Organizations' (World Bank, GTZ, Dutch Government) projects aim at developing rural electrification strategy. Japan Project consists in emission reduction. Consequently, more applications of RES technologies are included.

\section{Wind technical/economical challenges:}

Wind Power is still cannot compete with usual generation sources on a cost basis. This is attributed to the high initial investment due to the advanced technology in this field. The major challenges in using wind as a source of power are:

- Wind is natural phenomena, which could not predicted,. Also it is irregular and is not following constant pattern. Moreover, storing the electricity from the wind requires bulky, expensive and short-life span as the batteries. Hence, in areas where a large amount of energy is needed, one cannot depend completely on wind energy.

- Superior wind sites are often situated in remote locations, far-off from cities where the electricity is required. Transmission lines have to be built to bring the electricity from the wind farm to the city.

- Wind turbines usually produce less electricity than the average fossil fuelled power station, requiring various wind turbines to be built in order to make an impact.

- The commercial wind turbines are noisy; this imposes a constraint on the areas around wind farm.

- As the output power/voltage of the turbine-generator has wide variation; therefore interfacing circuits composed from industrial electronics have to be utilized for matching between the wind-generation-system and the grid. These circuits may cause significant problems for the grid in terms of conducted harmonics and electromagnetic interference.

\section{Conclusions:}

The following conclusions can be derived:

1. The wind energy, eco-friendly and sustainable energy source, is considered the future trendsetter for supplying the increased energy demands and protecting the environment.

2. Strong move undergoing worldwide for increasing the share of the wind power in the energy balance.

3. The recent technology advancements has the advantages of increasing the penetration of wind energy by increasing their reliability, and economical feasibility.

4. Integrating the wind power into national grids mandates elaborate approaches for resolving the related problems such as harmonics and other technical challenges.

5. The share of the Arabic region in wind power market is less than $1 \%$, although nearly all the countries in this region have promising wind capabilities.

6. Egypt has taken the first steps in terms of introducing the wind power in the energy 
balance. However, more work has to be carried out for developing a locally windbased technology.

Yemen tries hardly to start utilizing available wind power; however, this requires mandatory regional and international co-operation

\section{References:}

[1] New and Renewable Energy Authority - Annual Report (NREA) 2004/2005.

[2] Renewable Energy and Energy Efficiency Partnership (REAP) Programs, "Project Reports" May 2006.

[3] World Wind Energy Association (2008). Wind turbines generate more than $1 \%$ of the global electricity.

[4] http://www.eoearth.org/article/Wind.

[5] JetStream (2008). "Origin of Wind". National Weather Service Southern RegionHeadquarters.http://www.srh.noaa.gov/jetstream//synoptic/wind.htm. Retrieved 2009-02-16.

[6] Glossary of Meteorology (2009). "Thermal wind". American MeteorologicalSociety.http://amsglossary.allenpress.com/glossary/search?p=1\&query=t hermal+wind\&submit=Search. Retrieved 2009-03-18.

[7] H.L .Tolman, "Practical wind wave modeling" WSPC - Proceedings, October 29 (2008).

[8] I. R. Young, "Wind generated ocean waves". Elsevier(1999).

[9] Wind energy, applications guide, American Wind Energy Association January, 2001.

[10] http://www.windenergy.com/applications/telecommunications.htm.

[11] http://www.evancewind.com/applications/detail/telecom-off-grid.

[12] http://www.windenergy.com/applications/applications.htm.

[13] http://www.windenergy.com/applications/cathodic_protection.htm..

[14] http://www.windenergy.com/applications/water_pumping.htm.

[15] http://www.windenergy.com/applications/monitoring_sites.htm

[16] L.L, Freris, "Wind Conversion Systems", Prentice Hall International, London, 1990.

[17] World Wind Energy Report 2009" (PDF). Report. World Wind Energy Association. February 2010.

[18] "Wind Power Increase in 2008 Exceeds 10-year Average Growth Rate". Worldwatch.org. Retrieved 2010-08-29.

[19] 9thWorld Wind Energy Conference \& Exhibition Large-scale Integration of Wind Power, Istanbul, Turkey 15-17 June 2010.

[20] http://rhein.blogactiv.eu/2010/09/27/the-arab-world-starts-moving- towards-solar-andwind-energy/ 
[21] http://www.uv.es/EBRIT/art/oegypt00/01m4.gif

[22] http://www.eia.doe.gov/emeu/cabs/Egypt/Background.html

[23] S. Rahman, " Sustainable Wind Power Development Technology and Policy Perspectives" NSF Workshop on Wind Energy, 23March2010.

[24] A. Marzouk, " Zafarana wind farm facts and figures" Oct.19th, 2006.

[25] S. Aboulnasr" Financing Large Scale Wind Farms in Developing Countries Zafarana Wind Farm " April, 2006.

[26] A. M. Al-Ashwal " All Renewable Energy Applications in Yemen Best Practice" ISESCO Science and Technology Vision Volume 1 - May (45-50), 2005.

[27] Ministry of Water \& Environment and Ministry of Electricity, (2004): Yemen. Energy and Renewable Profile. Middle East \& North Africa renewable energy conference 2122 April, Sana'a, Yemen.

[28] AN. Celik (2004): On the distributional parameters used in assessment of the suitability of wind speed probability density function. Energy Conversion and Management; 45: $1735-1747$.

[29] M. Jamil, (1989): Wind power statistics and evaluation of wind energy density. Wind Eng; 18(5): 227-240. AH. Algifri, (1998): Wind energy potential in Aden-Yemen. Renewable Energy, Vol. 13, No. 2, pp. 255- 260.

[30] AN. Celik, (2003): A statistical analysis of wind power density based on the Weibull and Rayleigh models atthe southern region of Turkey. Renewable Energy; 29:593-604.

[31] Egbert Boeker, Rienk Van Grondelle (1999): "Environmental Physics. Second edition .John Wiley \& SONS, LTD.

[32] AH. Algifri, "Wind energy potential in Aden-Yemen. Renewable Energy", Vol. 13, No. 2, pp. 255- 2601998,

[33] "Energy and Renewable Profile, Republic of Yemen " REGIONAL CONFERENCE FOR RENEWABLE ENERGY, MIDDLE EAST AND NORTH AFRICAN COUNTRIES, April 21-23, 2004 Sana'a, republic of Yemen

[34] A. M. Al-Ashwal "Renewable Energy Potentials and Applications in Yemen"A Study performed according to UNIDO Request, May 2003.

[35] Renewable Energy - Market and Policy Trends in IEA Countries, 2004 edition.

[36] Annual Report of the New and Renewable Energy Authority (2003/2004).

[37] M. Simões, S. Chakraborty, and R. Wood, "Induction Generators for Small Wind Energy Systems," IEEE Power Electronics Society NEWSLETTER, pp. 19-23, 2006.

[38] J. T. Bialasiewicz, "Power-Electronics Systems for the Grid Integration of Renewable Energy Sources: A Survey," IEEE Transactions on industrial Electronics, vol. 53, p. 1002:1016, August 2006.

[39] S. Heier, Grid Integration of Wind Energy Conversion Systems. Hoboken, NJ: Wiley, 1998.

[40] G. L. Johnson, Wind Energy Systems. Englewood Cliffs, NJ: Prentice- Hall, 1985. 
[41] S. Muller, M. Deicke, and R. W. De Doncker, "Doubly fed induction generator systems for wind turbines," IEEE Ind. Appl. Mag., vol. 8, no. 3, pp. 26-33, May/Jun. 2002.

[42] L. Ake, S. Poul, and S. Fritz, "Grid impact of variable speed wind turbines," in Proc. EWEC, pp. 786-789, 1999.

[43] K. Protsenko; and D. Xu, "Modeling and Control of Brushless Doubly-Fed Induction Generators in Wind Energy Applications," IEEE Transactions on Power ElectronicS, vol. 23, pp. 1191-, MAY 2008.

[44] K. Tan; and S. Islam, "Optimum Control Strategies in Energy Conversion of PMSG Wind Turbine System without Mechanical Sensors" IEEE Transactions on Energy Conversion, vol. 19, pp. 392-399, JUNE 2004.

[45] M. Chinchilla, S. Arnaltes; and J. C. Burgos, "Control of Permanent-Magnet Generators Applied to Variable-Speed Wind-Energy Systems Connected to the Grid," IEEE Transactions on Energy conversion, vol. 21, pp. 130-135, March 2006.

[46] S. M. Husband and C. G. Hodge, "The Rolls-Royce transverse flux motor development," in IEEE International Electric Machines and Drives Conference, 2003. IEMDC'03. . vol. 3, pp. 1435 - 1440, 2003.

[47] L. Bor-Ren, and L. Hsin-Hung, "Multilevel PWM for single-phase power factor preregulator," in IEEE International Symposium on Circuits and Systems, 1998. ISCAS '98, vol.6, pp. 57-60, 1998.

[48] L. Bor-Ren, and L. Hsin-Hung, "Single-phase three-level rectifier and random PWM inverter drives," IEEE Transactions on Aerospace and Electronic Systems, vol. 35, pp. 1334-1343, October 1999.

[49] L. Bor-Ren, W. Chi-Nam, and L. Hsin-Hung, "Multilevel AC/DC/AC converter by using three-level boost rectifier and five-level diode clamped inverter," in Proceeding of IEEE International Conference on Power Electronics and Drive Systems, 1999. PEDS '99, vol.1, pp. 444-449, 1999

[50] S. Bum-Seok, G. Sinha, M. D. Manjrekar, and T. A. Lipo, "Multilevel power conversion- An overview of topologies and modulations strategies," in Proc. Int. Conf. Optimization Electr. and Electron. Equipments, OPTIM, vol. 2, pp. AD1-1-AD-2. , 1998.

[51] L. M. Tolbert, F. Z. Peng, and T. G. Habetler, "Multilevel converters for large electric drives," IEEE Trans. Ind. Appl., vol. 35, no. 1, pp. 36-44, Jan./Feb. 1999.

[52] J. Rodriguez, J.-S. Lai, and F. Z. Peng, "Multilevel inverters: A survey of topologies, controls, and applications," IEEE Trans. Ind. Electron.,vol. 49, no. 4, pp. 724-738, Aug. 2002.

[53] M. Marchesoni and M. Mazzucchelli, "Multilevel converters for high power AC drives: A review," in Proc. IEEE ISIE, Budapest, Hungary, pp. 38-43, 1993. 